\title{
Construction Ideas on Simulation Laboratory of Engineering Management
}

\author{
Feng WANG ${ }^{1, a}$, Ning ZHANG ${ }^{2, b}$, Jiaxiong WU ${ }^{1, c}$ \\ ${ }^{1}$ College of Civil Engineering, Dalian Nationalities University, Dalian 116650, China \\ ${ }^{2}$ School of Fashion, Dalian Polytechnic University, Dalian 116003, China \\ aemail:win_0803@163.com, bemail: zhangninglady@sina.com, cemail: wujiaxiong2015@163.com
}

Keywords: Project management; Building information modeling; Sand table simulation; Emulation laboratory

\begin{abstract}
The project management major is characterized by deciding that the project management laboratory should have simulation and emulation effects on the whole process of the construction project. According to the characteristics of experiment on project management major, the construction thoughts of the project management simulation laboratory are given. The recommended laboratory hardware comprises project management sand table, BIM software, tendering and bidding simulation system, project cost software, etc. The software includes project case library, teaching program and aided teaching materials and laboratory operation mode. The recommended laboratory can be used for simulation and emulation on each phase of the construction project, so that students can be well familiar with each link of the construction project before practical work, therefore, all kinds of professional knowledge is well mastered, various skills are cultivated, and various abilities are developed.
\end{abstract}

\section{Introduction}

At present, difficult employment of graduates and low employment starting points become social hot topics. The reason for this is that in an increasingly-competitive market environment, the time for talent training by enterprises is shortened, and talents frequently flow, so that the enterprises are more and more pragmatic about employing the experienced talents. Under this background, new challenges to colleges and universities are brought, and both colleges and universities only can gradually adapt to the development demands of the society through constantly adapting to the society and improving the students' practice ability ${ }^{[1]}$. Undergraduate education should consider the cultivation of professional theoretical ability and practicing ability concurrently. To achieve this goal, a new talent cultivation plan should be reestablished to have the teaching contents updated and the teaching methods innovated. However, although a lot of undergraduate schools in our country have a unanimous common view on the philosophy of applied undergraduate talent cultivation in perception, they still appear to be backward and lack in respect of teaching methods and teaching means.

As the project management major is based on the cultivation of applied talents, under normal conditions, there are three employment directions for the students majoring in project management, namely Consulting Firm, Employer and Contractor. No matter which work units are selected by the students, their works are aimed at the management of the whole process or a certain process of the construction project $^{[2]}$. Under the current employment situations are that the graduates are required by the employment units to skillfully work in their positions, both colleges and universities only can reduce the students' employment pressure through providing more practice opportunities. In order to cultivate the practice ability of the students majoring in project management, the construction and the development of the project management laboratory become especially important ${ }^{[3]}$.

\section{Characteristics of Experiment on Project Management Major}

The project management major belongs to management science and engineering type and 
stretches across two disciplines, namely engineering and management. Compared with an ordinary experiment on engineering major, the experiment on project management major has the following characteristics: (1) Different course natures. As four parts, namely technology, economy, management and law are included in the project management major, they should also be included in the corresponding experiment. There into, the practice ability training for technology can be performed in the ordinary project laboratory, like construction material laboratory; the practice ability training for economy, management and law must depend on the project management simulation and emulation laboratory, and a lot of experiments on project management major, which is related to economy, management and law, is often based on the simulation on market environment, economic system and humanities and social sciences; a larger difference between simulation system construction and engineering test decides a difference between experiment on project management and experiment on ordinary engineering. (2) Different laboratory functions. The main function of the project management laboratory is to utilize professional software and special simulation teaching system to simulate the actual operation processes of the project management activities, and through experiment, the students can be familiar with the whole process of project construction and project management to realize the integration of theory and practice. Therefore, the software environment is the core of simulating the laboratory construction.

In conclusion, the experiment on project management major is mainly characterized by simulation and emulation on the whole process of the construction project.

\section{Construction of Project Management Simulation Laboratory}

A hardware platform and a software platform should be mainly constructed, wherein the hardware platform strives for realizing reality and virtual interaction; the software platform mainly means the construction of the experiment curriculum system and also includes the design of laboratory running system and mechanism.

\section{Hardware platform}

1) Project management sand table

The project management sand table ${ }^{[4]}$ plays a role in completing the project. Every 5-6 students form a stimulated project department and stimulate different posts to experience the whole process of project management in a stimulated project environment.

2) BIM software

BIM (building information modeling) technology has obtained a great number of achievements in the construction project field in America, Japan and other developed countries and also received much attention at home. It is very important to master the BIM software by the students majoring in project management.

3) Tendering and bidding simulation system

Tendering and bidding can be completed within a short time through the tendering and bidding simulation system. By means of the thought of the project management sand table, the students can be divided into several groups to complete, and each student can play a role to complete respective works and experience each link in the tendering and bidding processes ${ }^{[5]}$.

4) Project management software

The commercialized project management software is an important means to complete project progress plan, capital plan, resource plan and the like. The project management software used in the laboratory should be under the university-enterprise cooperation background.

5) Project cost software

The calculation on bill of quantities, the cost control, the bid compilation, the bid price and other job contents can be completed through the project cost software. Through selecting the commercial cost software being mature in technology platform and large in market share, the employment of students will be facilitated.

The relationship between the hardware of laboratory and the corresponding professional knowledge and skills is shown in Table 1. 
Table 1. The laboratory hardware and the corresponding professional knowledge and skills

\begin{tabular}{|c|c|}
\hline Hardware of laboratory & Professional knowledge of skills \\
\hline \multirow{3}{*}{$\begin{array}{l}\text { Tendering and bidding } \\
\text { simulation system }\end{array}$} & Engineering bidding \\
\hline & Compilation of business bid \\
\hline & Compilation of pre-bidding construction organization design \\
\hline \multirow{3}{*}{ Project management sand table } & Construction organization and management \\
\hline & Engineering material procurement and management \\
\hline & Schedule management; Cost management; Contract management \\
\hline \multirow{4}{*}{ BIM software } & Data model of building engineering \\
\hline & Construction process simulation \\
\hline & Cost management; Quality management; Safety management \\
\hline & Crash test \\
\hline \multirow{4}{*}{ Project management software } & Construction organization and management \\
\hline & Engineering material procurement and management \\
\hline & Contract management and claims \\
\hline & $\begin{array}{l}\text { Schedule management; Cost management; Quality management; } \\
\text { Safety management }\end{array}$ \\
\hline \multirow{2}{*}{ Project cost software } & Engineering cost \\
\hline & Cost management \\
\hline
\end{tabular}

\section{Software Platform}

1) Establishment of project case library

The project case library should be established based on practical projects, and the project contents should be determined according to the link demands of practice teaching and cover project name, project overview, a full set of design documents of the projects, project tendering documents, project budget template, project contracts, project site pictures, project management documents, project teaching links, case using rules and the like. The overall planning and the demands of the project case should be formulated according to training plans, the case should cover main engineering category adapting to project management, like housing construction projects, road and bridge projects, water conservancy and hydropower construction projects and the like.

2) Compilation of course teaching program and aided teaching materials

Course teaching program, instructors and aided teaching materials are important premises of smoothly completing the experiment. Each experiment in the laboratory should meet the requirements of the teaching program of served professional courses. Therefore, the teaching program should be closely cooperated with that of the professional courses in compilation. Operation rules must be formulated in the instructor based on the practical project operation mode.

3) Operation mode of comprehensive project management laboratory

All experiments opened in the comprehensive project management laboratory and the design courses should be closely related to the relevant courses in the professional teaching training plan in opening sequence and respectively arranged according to different terms. The setting and the operation of all experiment courses in the laboratory for project management major should be based on the case library and undergo the following steps:

(1) Extracting the case projects conforming to the experiment conditions.

(2) Selecting corresponding experiment hardware and software facilities according to the experiment and the design contents. 
(3) Performing case engineering data entry.

(4) Completing the experiment and the design contents according to the teaching program and the instructor.

(5) Submitting the experimental reports or achievements.

\section{Summary}

The project management major is characterized by deciding that the project management laboratory should have simulation and emulation effects on the whole process of the construction project. According to the characteristics of experiment on project management major, the construction thoughts of the project management simulation laboratory are given. The recommended laboratory hardware comprises project management sand table, BIM software, tendering and bidding simulation system, project cost software, etc. The software includes project case library, teaching program and aided teaching materials and laboratory operation mode. The laboratory construction will provide favorable ways and means for teachers to carry out teaching, so that the students can fully understand the course content. The establishment of the project management simulation laboratory will be beneficial to pushing the practice teaching ability of the project management major and realizing the cultivation of applied talents in a real sense. The design and construction scheme of the simulation laboratory have certain demonstration significance on the practice teaching reform in domestic project management major.

\section{Acknowledgement}

In this paper, the research was sponsored by the project of teaching reform and education quality evaluation of Liaoning Education Evaluation Association (Grant NO. PJHYYB15047) and the project of characteristic specialty construction of Dalian Nationalities University.

\section{References}

[1] Yun Li. Reforming the Civil Engineering Management Courses and Training Students' Engineering Management Ability[J] Journal of Chongqing Jiao Tong University(Social Sciences Edition), 20044 (4) 127-130. (in Chinese)

[2] Lianbo Zhu, Hong Ren. Study on training university students of construction management in the 21st century. Journal of Architectural Education in Institutions of Higher Learning, 200615 (4) 59-62. (in Chinese)

[3] Junjie Chen, Min Tian, Jingwen Zhang. Exploration and practice of the comprehensive experiment in project management[J]. Research and Exploration in Laboratory, 2010 (3) 130-132. (in Chinese)

[4] Hongtao Li. Project management (PMST) sand table simulation training course [M]. Chongqing: Chongqing University Press, 2013. (in Chinese)

[5] Xiuying Hu. Research and practice on the design of engineering bidding simulation course. Sichuan Building Materials, 201238 (3) 255-256. (in Chinese) 